\title{
CIDADES E INTELECTUAIS: os "nova-iorquinos" da Partisan Review e os "paulistas" de Clima entre 1930 e 1950
}

\author{
Heloisa Pontes
}

Neste artigo pretendo explorar as intersecções entre espaço urbano, instituições acadêmicas, organizações culturais e formas de sociabilidade, por um lado, e suas inflexões na modelagem de distintas gerações de intelectuais, por outro. ${ }^{1}$ Tendo por base os trabalhos de Mary Gluck (1985) sobre a geração de Lukács em Budapeste, de Clarck (1986) sobre Paris e a pintura da "vida moderna", de Schorske (1988) sobre o modernismo em Viena, de Raymond Williams (1982) sobre o grupo Bloomsbury, de Thomas Bender (1993) sobre Nova York e seus intelectuais e de Maria Arminda Arruda do Nascimento (2001) sobre a relação entre sociedade e cultura em São Paulo, pretendo abordar, numa perspectiva comparativa, as similitudes e as diferenças entre os intelectuais "paulistas" da revista Clima (editada entre 1941 e 1944) e

Artigo recebido em outubro/2002

Aprovado em abril/2003 os "nova-iorquinos" nucleados pela Partisan Review (lançada em 1937). Delineados os termos e o conteúdo substantivo da comparação proposta, o artigo se fecha com uma tentativa, ainda exploratória, de pensar esse círculo de intelectuais norteamericanos à luz do modelo teórico construído por Elias para analisar as dimensões estruturais recorrentes na figuração "estabelecidos-outsiders".

Os editores da Partisan Review (Philip Rahv, William Phillips, Dwight Macdonald, Clement Greenberg, Mary McCarthy, mais tarde, Delmore Schwartz e William Barrett) e seus colaboradores (Alfred Kazin, Lionel Trilling, Diana Trilling, Irving Howe, Elizabeth Hardwick, Hannah Arendt, Nicolas Chiaramonte, Sidney Hook, Edmund Wilson, Meyer Schapiro, entre outros) renovaram a discussão sobre a relação entre modernismo nas artes e radicalismo na política. Anti-stalinistas fervorosos, de início marxistas, alinhados ao campo político da esquerda norte- 
americana, foram aos poucos migrando do seu pólo mais radical, representado pelos trotskistas, para o campo dos liberais democratas e dos conservadores. ${ }^{2}$ Herdeiros do legado modernista, familiarizados com o cosmopolitismo no plano da cultura, atentos à produção intelectual e artística local, eles marcaram a cena cultural nova-iorquina dos anos de 1930, 1940 e 1950 e contribuíram decisivamente para a valorização, em novas chaves, da cultura norte-americana. Como intelectuais generalistas, pertenciam a uma geração que tinha a literatura como centro de sua educação. Como críticos da cultura, resenhistas e polemistas, fizeram do ensaio o meio por excelência de expressão e encontraram nas revistas literárias e políticas o seu fórum institucional de divulgação. Como integrantes de um círculo predominantemente literário, não se restringiram aos seus campos de especialização, diferenciando-se, assim, dos acadêmicos em sentido estrito. Oriundos, a maioria deles, de famílias pobres de judeus imigrantes vindos da Europa Oriental para os Estados Unidos - onde nasceram - fizeram nome na contra-mão da experiência dos pais, graças ao desempenho brilhante que tiveram nas escolas públicas e, posteriormente, nos centros de ensino superior de Nova York.

Desse encontro entre os filhos talentosos da segunda geração de imigrantes judeus destituídos de capital social e econômico com alguns jovens norte-americanos promissores, oriundos de famílias brancas, protestantes e abonadas, em uma conjuntura fervente de radicalismo político, depressão econômica e em meio a uma cidade em intensa transformação, como Nova York, constitui-se uma das mais inquietantes e intrigantes gerações de intelectuais norte-americanos. ${ }^{3}$ Entre os judeus desse círculo, que atingiram a vida adulta no final dos anos de 1920 ou começo de 1930, encontram-se: Philip Rahv (1908-1973), William Phillips (1907-), Clement Greenberg, (1909-1994), Lionel Trilling (1905-1975), Diane Trilling (1905-), Meyer Schapiro (1905-1996) Sidney Hook (19021989). Incluem-se também os nascidos na década de 1910, que atingiram a maturidade no final dos anos de 1930, como Lionel Abel (1910-), Alfred Kazin (1915-), Delmore Schwartz (1913-1966),
Daniel Bell (1919-), e outros mais jovens, nascidos no decênio de 1920, como Irving Howe (1920-1993) e Nathan Glazer, entre outros. A eles juntaram-se os não judeus, Frederick Dupee (1904-1979), Wiliam Barrett (1913-), Dwight Macdonald (1906-), Mary McCarthy (1912-1989) - na condição de editores da Partisan Review - e colaboradores como Edmund Wilson (1895-1972), Elizabeth Hardwick (1916-), entre outros. Com exceção de Barrett, os demais provinham de famílias norte-americanas prósperas e protestantes. Por fim, cabe mencionar os europeus refugiados que chegaram nos Estados Unidos no início da Segunda Guerra Mundial e se integraram ao círculo: Nicolas Chiaramonte e Hannah Arendt (1906-1975) - da mesma etnia da maioria deles, com a diferença que seus pais eram judeus alemães, educados e de classe média alta.

$$
* * * *
$$

Até os anos de 1920, os intelectuais e escritores norte-americanos tinham a Europa como rota obrigatória e referência fundamental, sentindo-se muitas vezes como uns "desterrados na própria terra" (para usar uma célebre expressão de Sérgio Buarque de Holanda que se aplica tanto à intelectualidade brasileira como à norte-americana na época). Mas a partir dos anos de 1930, com a Depressão, e de 1940, com a entrada dos Estados Unidos na Guerra e sua progressiva hegemonia econômica e política, somadas à consolidação da sua cultura acadêmica e de suas instituições culturais, observa-se uma reorientação da intelectualidade local com as suas congêneres européias. Paris deixara de ser a capital cultural do mundo. Nova York, com seus novos movimentos artísticos, sobretudo com o abstracionismo, seus críticos de arte, seus museus e poderosos mecenas, convertese no novo pólo de atração mundial. Contribuíram para isso não só as instituições locais, respaldadas por suas elites dirigentes, como os novos círculos de intelectuais, entre eles os intelectuais nova-iorquinos ligados a Partisan Review.

Parecidos e distintos dos "paulistas" de Clima, eles oferecem um bom contraponto para uma sociologia da vida intelectual. Sobretudo, se ao 
lado da recuperação das especificidades das histórias culturais e intelectuais das cidades de Nova York e São Paulo, formos capazes de avançar na investigação de um conjunto de problemas sociológicos pertinentes para o adensamento da perspectiva comparativa. Entre eles: a relação entre origem social (e etnia, no caso norte-americano), transformações na estrutura social e no campo cultural das respectivas cidades e suas implicações nas trajetórias dos integrantes mais expressivos desses grupos; o lugar do ensaio na modelagem da identidade intelectual desses grupos; as relações (e tensões) desses intelectuais com a cultura acadêmica e política da época; o impacto e a influência que receberam dos intelectuais e artistas europeus, direta ou indiretamente, seja em razão da importância que os últimos tiveram na montagem de instituições universitárias (como a Faculdade de Filosofia da Universidade de São Paulo e a New School for Social Research de Nova York), seja pelo impacto da sua presença na cena cultural e intelectual das respectivas cidades, onde se refugiaram antes ou durante a Segunda Guerra em decorrência de perseguições políticas e étnicas. Além dessas dimensões, outra que parece importante para a análise desses círculos de intelectuais, de suas experiências sociais e do tipo de sociabilidade praticada por eles diz respeito às inflexões de gênero na conformação desses grupos.

Começo então pela última questão, relativa à posição das mulheres na divisão do trabalho e no universo de sociabilidade desses círculos de intelectuais. Mas no lugar de construir, de saída um argumento analítico, vou fazer aquilo que todo antropólogo, por ofício ou vocação, pratica no dia-a-dia do seu métier: contar casos, com a atenção voltada para as dimensões menos óbvias da interação social, como meio de apreender a dinâmica vívida e tumultuada da vida social.

\section{Sociabilidade, posição das mulheres e divisão do trabalho intelectual}

Nova York, final de 1930. Num domingo de manhã, quatro jovens e uma jovem dirigem-se a um encontro que será decisivo na vida de todos eles. William Philips, Philip Rahv, Dwight Macdonald, Fred Dupee e Mary McCarthy preparam-se para almoçar com um dos mais renomados críticos literários da época, Edmund Wilson, de quem esperam o apoio necessário para a consolidação da revista que estavam lançando. Queriam dele a chancela do nome próprio, este bem simbólico dos mais prezados nos campos de produção cultural e intelectual, como mostrou Bourdieu (1984), capaz de produzir por si só uma curiosa "contaminação de prestígio" para todos e tudo que gravitam ao seu redor. "Glória de empréstimo", diria outro arguto analista da vida em sociedade, no caso o nosso escritor Machado de Assis.

Os jovens de Nova York sabiam disso por Conhecimento direto da cena intelectual da época e, indiretamente, pela experiência social que conformou a trajetória de todos. Dois deles eram judeus e os demais vinham de famílias de classe média alta, unidos pelo projeto comum de editar uma revista de cultura, a Partisan Review, engajada num dos poucos e precisos momentos de radicalismo político que tomou conta da parcela mais atuante e significativa da intelectualidade nova-iorquina da época. Adeptos do marxismo, críticos ferrenhos do stalinismo, gravitando num caldo de cultura que unia o cosmopolitismo no plano da cultura ao radicalismo na política, eram próximos do trotskismo e admiradores entusiastas de Trotski. Em disputa aberta com os comunistas e com o Partido, eles precisavam do aval de nomes de peso, como o de Edmund Wilson, para galgarem posições mais sólidas e garantir uma visibilidade maior para a revista que estavam em vias de lançar.

Todos estavam ansiosos para o encontro, preocupados em causar uma boa impressão no convidado, mas apenas um se vestiu de um modo ligeiramente inadequado para a ocasião. No caso, Mary McCarthy que, no lugar de adotar o estilo "nervosamente displicente" dos rapazes, sobre-investiu na escolha da roupa e apareceu linda, com um vestido preto de seda, mais apropriado para uma recepção de casamento do que para um encontro de negócios promovido no escritório de uma revista radical. De lá partiram todos para um restaurante na Union Square. 
Eles estavam na faixa dos vinte anos e Edmund Wilson na meia-idade. A única mulher do grupo naquela ocasião, Mary não foi particularmente notada por Wilson que conversou especialmente com Dwight Macdonald e com Fred Dupee. Com exceção de Dwight - o mais "bem nascido" do grupo -, todos os demais estavam nervosos, sentiam-se com a língua presa e aguardavam com ansiedade o garçom para pedirem os drinques. Menos Edmund Wilson que com um gesto irritado declinou a oferta. Eles entenderam rápido o recado e fizeram o mesmo, de modo que o almoço, a seco, rolou menos solto do que desejavam e centrou-se em torno das proposições programáticas da Partisan Review, do anti-stalinismo convicto de seus editores e dos números que eles estavam preparando para dar seqüência ao lançamento, em 1937, da revista. Wilson concordou que eles deveriam tentar conseguir de Trotski uma contribuição assinada. ${ }^{4}$ Em seguida falaram do livro que Edmundo Wilson estava escrevendo sobre o marxismo em conexão com a Revolução Russa. O livro, Rumo à estação Finlândia, só seria lançado em 1940. Mas bem antes disso, Wilson colaboraria com a revista e causaria uma revolução na vida de alguns de seus editores.

Não neste almoço, que correu dentro do esperado. Mas no encontro seguinte que ele teria com Mary McCarthy, a crítica de teatro regular da revista, que aos 25 anos, divorciada do seu primeiro marido, o ator Jonhsrud, estava vivendo com Philip Rahv, o único imigrante do grupo, que chegara aos Estados Unidos em 1922, sozinho, com 14 anos, para morar com um irmão mais velho em Oregan, enquanto o resto de sua família permanecia na Palestina, depois de uma passagem pela Áustria, motivada pelo pogrom de que fora vítima em 1917. Autodidata, não completou o segundo grau e fez toda a sua formação como leitor obstinado nas bibliotecas públicas norte-americanas. Em 1932, mudou-se para Nova York, entrou em contato com os comunistas, ingressou no Partido e dois anos depois, junto com o amigo William Phillips, lançou o embrião da Partisan Review, patrocinada pelo John Reed Club. O empreendimento ocorreu em meio aos processos de Moscou movidos por Stálin. Estes, somados à visão dos comu- nistas norte-americanos sobre o lugar da cultura e de sua função atrelada a objetivos políticos, motivaram a ruptura de Phillips e Rahv com o Partido. O nome da revista, porém, ficou como propriedade intelectual deles e foi reutilizado no lançamento da nova Partisan Review em 1937.

O mais politizado do grupo, Rahv parecia, naquela ocasião, particularmente incomodado com o convite que Mary recebera, da parte de Edmund Wilson, para um segundo encontro que o excluía juntamente com os demais rapazes da revista. Eles, ao mesmo tempo em que insistiam para que ela fosse, estavam temerosos do seu desempenho, pois não achavam que Mary fosse muito bem informada no plano político. Por isso não escondiam o medo de que a inexperiência política dela pudesse fazer com que a revista parecesse ingênua aos olhos do crítico experiente. Ela que tinha uma história de vida singular - órfã de pai e mãe, falecidos praticamente no mesmo dia em decorrência da gripe espanhola de 1918, educada até os 12 anos por um casal aterrorizante de tios-avós ressentidos e a partir daí pelo avô materno, advogado renomado, protestante, casado com uma judia excêntrica - não entendia, por exemplo, as razões substantivas que levaram os revolucionários russos a assassinarem o Tsar e sua família. Não porque fosse desinformada e sim porque sua formação fora feita em colégios católicos e completada no famoso college de Vassar, onde estudavam as moças talentosas de elite da época, como a própria Mary e a poetisa Elizabeth Bishop, por exemplo.

Se a mudança para Nova York, em 1936, alterara radicalmente o destino de Mary, em 1938, quando do seu segundo encontro com Wilson, ela que já estava um passo a frente das moças da sua época em termos da vida amorosa e, em certo sentido, profissional ainda estava um passo atrás, segundo a avaliação dos rapazes da revista, do clima de radicalismo político da época. Por isso resolveram "treiná-la" para o encontro. Entre as medidas adotadas, além das conversas sobre temas mais políticos, três martines secos, consumidos um pouco antes do encontro. De modo que Mary já chegou calibrada para um jantar que todos, ela inclusive, supunham que deveria trans- 
correr no padrão do almoço anterior: conversas variadas sobre cultura e política, conduzidas com fluência e a seco por Edmund Wilson.

O que "rolou", porém, estava bem longe do script imaginado. Para surpresa de Mary, Wilson bebia, e bem, e só não fez isso no primeiro encontro porque naquele dia ele acordara de ressaca. Sem coragem de recusar os drinques oferecidos por ele e menos ainda de mencionar os martines consumidos antes, ela bebeu mais que o habitual. Resultado: Mary se empolgou, roubou a cena, soltou a língua e, encontrando em Wilson um ouvinte atento, fez da sua vida o tema da noite. Depois apagou. Quando voltou a si, no dia seguinte, estava deitada na cama, num quarto desconhecido. Sua primeira medida foi certificar-se se estava sozinha ou acompanhada. Nem uma nem outra no sentido que a atemorizara. Margareth, a outra convidada do jantar da véspera, estava dormindo na cama ao lado e Wilson, que apenas depositara as duas no hotel e incumbira a amiga de passar a noite com a Mary, encontravase em casa. 5

No terceiro encontro, Mary e Wilson acabariam a noite juntos, na cama do escritório da casa dele. De lá para frente, a história seguiria o curso previsível dos relacionamentos triangulares. Dividida e dilacerada, Mary não sabia se rompia com Philip Rahv ou com Wilson. Acabou casada com Wilson, 17 anos mais velho que ela, seu segundo marido oficial e pai de seu único filho. Com o casamento, Mary se afastaria da Partisan Review e se reorientaria para a ficção. Em grande parte graças à influência e aos métodos pouco usuais de Wilson que, acreditando no talento da mulher como escritora e duvidando da qualidade da crítica teatral de Mary, costumava trancá-la, às tardes, no escritório, para que ela se disciplinasse na prática da escrita cotidiana.

Esta história resumida de uma vida atribula$\mathrm{da}$, fascinante e instigante como foi a de Mary McCarthy - memorialista de mão cheia, conhecida não só por seus talentos literários mas pela sua inteligência cortante e língua ferina ${ }^{6}$ - oferece um contraponto interessante para introduzirmos o outro termo da comparação proposta: o Grupo
Clima, seu universo de sociabilidade, o lugar e a posição das mulheres.

\section{O Grupo Clima}

Formado no início de 1939, em São Paulo, por jovens estudantes da Faculdade de Filosofia, Ciências e Letras (nascidos entre 1916 e 1920), unidos por fortes laços de amizade e por uma intensa sociabilidade, o Grupo Clima era integrado por Décio de Almeida Prado, Paulo Emílio Salles Gomes, Lourival Gomes Machado, Ruy Galvão de Andrada Coelho, Gilda de Mello e Souza, entre outros. Juntos lançaram-se na cena cultural paulista por meio de uma modalidade específica de trabalho intelectual: a crítica aplicada a teatro, cinema, literatura e artes plásticas.

Décio e Paulo Emílio, amigos desde os tempos de colégio, eram filhos de médicos com destacada projeção nos círculos da elite paulista da época. O mesmo aplicava-se ao pai de Antonio Candido, médico conceituado, com vasta clientela no interior de Minas. Como o pai de Décio, ele também se formara na Faculdade de Medicina do Rio de Janeiro e interessava-se tanto pela medicina como pela literatura. Rui Coelho, filho de um advogado de renome, e o mais novo do grupo, publicou seu primeiro trabalho - um longo ensaio sobre Proust - aos 21 anos, na revista Clima, que projetaria todos na cena cultural paulista, Gilda inclusive - a prima de segundo grau do "papa" do modernismo brasileiro, Mário de Andrade, e futura mulher de Antonio Candido.

As afinidades que os uniram, decorrentes de suas origens sociais semelhantes, da vivência parecida que tiveram na infância e adolescência, do tipo de formação cultural que receberam de suas famílias e das escolas que freqüentaram, foram reforçadas e sedimentadas ao longo do período em que cursaram a Faculdade de Filosofia. Para muitos deles, essa instituição representou bem mais do que um espaço de profissionalização. Foi, antes de tudo, o centro irradiador que conformou o universo de sociabilidade do grupo. Ali construíram as relações pessoais, intelectuais, afetivas e, em alguns casos, amorosas, que marcariam para 
sempre suas vidas. Tais foram, por exemplo, os casos de Décio e Ruth de Almeida Prado e de Antonio Candido e Gilda de Mello e Souza.

A única mulher do grupo que conquistou um "nome próprio", em razão de sua trajetória acadêmica e dos trabalhos que produziu nas áreas de sociologia e estética, o caso de Gilda de Mello e Souza é particularmente interessante para pensarmos a assimetria das relações de gênero no interior desse círculo e, ao mesmo tempo, para avançarmos na comparação proposta entre os intelectuais "paulistas" do grupo Clima e os intelectuais nova-iorquinos da Partisan Review.

Enquanto no final dos anos de 1930, em Nova York, as mulheres do grupo já podiam praticar uma sociabilidade arrojada, como vimos rapidamente a partir do caso da escritora Mary McCarthy, em São Paulo, as moças e os rapazes de Clima eram bem mais comportados. Relembrando esse período, Gilda afirma que

\footnotetext{
[...] saíamos muito juntos. A partir de certo momento, creio que só conseguíamos nos divertir se estivéssemos juntos. Em geral nos encontrávamos no fim da tarde, nas aulas de Maugüé. Era já noitinha quando saíamos dos cursos para a réplica ligeiramente européia da Praça da República de então. Os plátanos, a algazarra dos pardais, o vento frio, o eco francês da voz de Maugüé - que carregando a sua serviette, ia à nossa frente, discutindo a aula com algum aluno - tudo isso nos envolvia numa doce miragem civilizada. Se não tínhamos nenhuma tarefa escolar urgente, seguíamos dali para o nosso quartel-general, a Confeitaria Vienense, na Barão de Itapetininga. Era ali que entre um croissant e um ice chocolate alemão (pois ninguém bebia no nosso grupo) combinávamos uma esticada ao cinema, quase sempre um filme francês [...] (Mello e Souza, 1984, p. 135).
}

Esse aspecto bem comportado da sociabilidade do grupo contrasta com a dos intelectuais nova-iorquinos. Menos atirados que eles, os integrantes de Clima eram antes de tudo universitários recatados. Assim, se em termos da sociabilidade mundana, os nova-iorquinos estariam mais próximos dos nossos modernistas, do ponto de vista do perfil intelectual do grupo, deles se afastam em aspectos decisivos. Críticos de cultura em sua maio- ria, com exceção de alguns poucos escritores, ${ }^{7}$ eles se parecem, intelectualmente, mais com os membros de Clima do que com os modernistas.

Essa dimensão é central tanto para a comparação que estou propondo entre eles, como para discutirmos a posição que as mulheres tinham no interior desses círculos. Nesse sentido, se a história narrada anteriormente com a intenção de delinear a sociabilidade do grupo - as peripécias amorosas de Mary McCarthy e a posição que ela ocupou na divisão do trabalho intelectual da então recém-lançada Partisan - nos lembra (e muito) as vivências também atribuladas e fascinantes das nossas modernistas Tarsila do Amaral, Anita Malfatti e Patrícia Galvão, dela se distingue em vários aspectos. A começar pela formação universitária em literatura que Mary recebeu em Vassar, o que a habilitou a estrear na cena cultural nova-iorquina como crítica de teatro - e só um pouco mais tarde como escritora, voltada também para a crítica de cultura. Tarsila do Amaral (1886-1973) e Anita Malfatti (1889-1964) eram pintoras e não críticas. ${ }^{8}$ E se Patrícia Galvão (1910-1962) - mais conhecida como Pagu - fez as duas coisas como Mary, isto é, escreveu ficção e crítica de teatro, isso se deu numa conjuntura distinta da sua aparição no modernismo, quando era ainda uma colegial, transformada "em boneca" pelo casal Tarsila e Oswald de Andrade. Antes, é claro, do romance avassalador que teve com Oswald e do nascimento, em 1930, do filho de ambos, Rudá de Andrade, e da entrada deles no Partido Comunista em 1931. A primeira de uma série de acontecimentos políticos que marcariam a vida de Pagu no decênio de 1930: das viagens à volta ao mundo (quando estréia como repórter), aos longos meses que morou em Paris (sem o marido e o filho), onde fora presa em julho de 1935, como militante comunista estrangeira. Repatriada, voltaria ao Brasil e, por duas vezes, em 1935 e 1938, seria presa novamente. Libertada em julho de 1940, depauperada e magérrima, Pagu iniciou um romance com Geraldo Ferraz, com quem viveria até o fim da sua vida. De modo que foi só nos anos de 1940 que ela retomou a vida intelectual, ligando-se ao periódico socialista Vanguarda Literária, em 1945, e iniciando, no ano seguinte, a sua colaboração regular no Su- 
plemento literário do Diário de São Paulo. Sua estréia como crítica de teatro, porém, só ocorreria em 1957, quando ela e Ferraz já estavam residindo em Santos.

Se me estendi no caso de Pagu foi para mostrar que tanto ela como as nossas modernistas pintoras são e não são comparáveis à escritora norte-americana Mary McCarthy. São, se usarmos como critério as vidas amorosas atribuladas ou tumultuadas que tiveram e o fato de terem sido mulheres que desafiaram os padrões dominantes de moralidade e de gênero na época. Não são, se mantivermos o foco no perfil dos círculos intelectuais e artísticos a que pertenceram. Nesta dimensão, a comparação de Mary com Gilda de Mello e Souza mostra-se pertinente, pois tanto uma como outra, além de serem produtos da vida universitária em sua interface com o sistema cultural mais amplo das cidades em que construíram suas vidas profissionais, fizeram parte de círculos com um perfil intelectual parecido. No caso de Gilda e de outras mulheres da sua geração que integraram o Grupo Clima, o acesso à formação intelectual que tiveram na Faculdade de Filosofia, somado à vivência inédita de uma sociabilidade fortemente ancorada na vida universitária, permitiu a várias delas reorientar o papel social para o qual haviam sido educadas: mães e donas de casa. O impacto dessa experiência renovadora propiciada pela Faculdade foi enorme, sobretudo para aquelas que efetivamente tentaram inventar para si um novo destino, como foi o caso de Gilda. Mas isso se deu às custas de conflitos, inseguranças e dilemas muito específicos. Sobretudo no início, quando não se sentiam socialmente seguras para se inserirem no campo intelectual predominantemente masculino da época. As dificuldades preliminares que enfrentaram, transmutadas sob a forma de inseguranças pessoais, foram sendo contornadas, mas não eliminadas, à medida que construíam novos modelos de conduta e atuação.

No período em que a revista Clima foi produzida, estava em curso a montagem de um novo sistema de produção intelectual, e iniciavam-se as transformações dos papéis femininos que Gilda de Mello e Souza e outras mulheres de sua gera- ção iriam viver, com as ambigüidades e dilemas mencionados acima. Nesse contexto de dupla redefinição, Gilda, que estreara em Clima com um conto, seguindo o conselho de Mário de Andrade de que seria bom para a revista ter alguém dedicado exclusivamente à ficção, abandonou o papel que lhe fora reservado e parou de escrever ficção. Seu gesto, reforçado ao que tudo indica pela ausência de críticas claramente favoráveis à sua produção como contista, teve um sentido preciso: recusar a posição e o papel que os companheiros da revista lhe atribuíram. Insurgir-se contra as duas modalidades socialmente mais adequadas de expressão intelectual para as mulheres na época, a ficção e a poesia, foi talvez o seu "primeiro ato de liberdade" ${ }^{10}$ ainda que arrevesado.

Enquanto Gilda largava a ficção para se lançar no campo universitário e na área da sociologia estética, Mary McCarthy deixava a crítica de teatro para se notabilizar como escritora. Diferenças de estilo, de personalidade, de parcerias amorosas e do campo intelectual em que ambas estavam inseridas. Mas ao lado dessas diferenças, inegáveis, é preciso sublinhar também as semelhanças, pois tanto uma como outra são impensáveis sem a presença das instituições de ensino superior, das transformações que estavam ocorrendo na estrutura social das cidades de São Paulo e Nova York no período, das novas modalidades de recrutamento social dos intelectuais e de expressão simbólica das dimensões de gênero.

\section{Os intelectuais de Nova York vistos de longe e de forma comparativa}

As relações que uniam esses intelectuais de Nova York eram, a um só tempo, morais, pessoais, políticas, e, em alguns casos, conjugais. Eles não apenas "envelheceram juntos" como aparecem, com muita freqüência, sob a forma de personagens nas memórias que escreveram. Retratos de época, de pessoas, de um universo intelectual e cultural específico, no interior do qual ganharam nome e autoridade - por si mesmos e como parte inseparável dos círculos a que pertenciam -, essas memórias são uma fonte preciosa para en- 
tendermos o tipo de sociabilidade que praticavam, as fofocas que circulavam na época, os amores, casamentos e separações, os conflitos, as inimizades, as alianças que fizeram. ${ }^{11}$

A profusão de conflitos entre eles ${ }^{12}$ contrasta com a ausência de atritos manifestos entre os integrantes mais expressivos do Grupo Clima, cujas relações foram marcadas pela convivência íntima e pela ausência de competição explícita. Isso se explica menos pela personalidade dos membros desses grupos e mais pelo tipo distinto de sistema cultural em que estavam inseridos.

No caso paulista e no início dos anos de 1940, segundo o então estreante de 22 anos, Antonio Candido, todos tinham "em preparo um trabalho de história, ou de sociologia, ou de estética ou de filosofia, como os maiores (da geração anterior) tinham romances" (Candido, 1945, p. 34). Com exceção de Gilda de Mello e Souza, que publicou primeiro ficção, todos os outros começaram com um artigo de crítica e não se aventuraram na poesia como os maiores da geração anterior. Nas palavras de Antonio Candido, emitidas no auge de sua juventude, todos eram "críticos e estudiosos 'puros', no sentido de que, neles, dominará sempre esse tipo de atividade" (Idem, ibidem).

Como produtos do novo sistema de produção intelectual implantado na Faculdade de Filosofia da Universidade de São Paulo, por intermédio dos professores estrangeiros (franceses, em particular), Antonio Candido e seus amigos mais próximos do Grupo Clima renovaram a tradição ensaística brasileira. Situados entre os literatos, os modernistas, os jornalistas polígrafos e os cientistas sociais, construíram seu espaço de atuação por meio da crítica, exercida em moldes ensaísticos mas pautada por preocupações e critérios acadêmicos de avaliação. O fato de atuarem ao mesmo tempo como críticos de cultura, acadêmicos e professores universitários sinaliza o alcance das transformações que estavam ocorrendo ao longo das décadas de 1940 e 1950 no sistema cultural paulista, decorrentes em larga medida da introdução de novas maneiras de conceber e praticar o trabalho intelectual. Nesse contexto, fizeram a "ponte" entre a Faculdade de Filosofia e as instâncias mais amplas de produção e difusão cultural da cidade.
Escrevendo sobre modalidades variadas da crítica de cultura, deram visibilidade à nova mentalidade universitária que estava sendo definida pela Universidade de São Paulo. Mas no lugar de fazerem uma crítica apoiada apenas na discussão de posições teóricas, centraram-se principalmente na análise interna da produção cultural veiculada no período. Além disso, cada um dos editores mais expressivos da revista Clima especializou-se numa área da cultura, que, embora fronteiriça, como a crítica literária, de cinema, de teatro, de artes plásticas, permitia aplainar os eventuais conflitos entre eles.

Em Nova York, por contraste, além da produção cultural e acadêmica ser bem mais segmentada e especializada na época, pesava ainda o fato de a maioria dos integrantes da Partisan estar voltada para a crítica literária como domínio principal de suas atividades intelectuais (descontados os casos dos críticos de arte, Clement Greenberg, Meyer Schapiro e Rosenberg).

Se ambos os grupos tinham em comum a crítica de cultura e o ensaio como modo privilegiado de expressão, o mesmo não se pode dizer a respeito da origem social de seus integrantes. Enquanto os membros de Clima pertenciam ao setor da burguesia formado por profissionais liberais, altos funcionários, fazendeiros e industriais médios; os intelectuais de Nova York - com exceção de uns poucos "bem nascidos", oriundos de prósperas famílias protestantes - eram provenientes sobretudo da segunda geração de famílias pobres de judeus imigrantes. Tanto num caso como no outro, essas injunções lhes davam "um ar de família, um viés definido de enxergar o real" (Mello e Souza, 1984, p. 135) - nas palavras precisas de Gilda de Mello e Souza, que, utilizadas para explicar as razões que propiciaram e alimentaram o convívio intenso de seu grupo de juventude, aplicam-se também aos intelectuais nova-iorquinos.

Se o "viés definido de enxergar o real" apresenta conteúdos distintos em função das experiências sociais diversas desses intelectuais, é preciso ressaltar a existência de um solo estrutural e institucional semelhante que torna possível e justifica a comparação proposta neste artigo. Em primeiro lugar, cabe sublinhar que eles deram prossegui- 
mento, em novas chaves, ao trabalho de consolidação da cultura moderna, cujo impulso inicial fora emitido pelos modernistas que os precederam. Tendo a França como modelo e, em vários casos, como lugar de moradia temporária, esses "repatriados começaram a se empenhar em produzir em casa o similar nacional" (Costa, 2001, p. 27). ${ }^{13}$ Repatriados simbólicos, no caso dos modernistas; reais, no caso de muitos dos intelectuais de Nova York ligados a Partisan Review, em razão da imigração forçada dos pais, por razões econômicas e perseguições religiosas, vítimas em sua maioria dos pogroms que tiveram lugar na Europa na segunda metade do século XIX.

Instalados em solo norte-americano, vivendo nos bairros "étnicos" de Nova York, sobretudo no Bronx, onde se concentravam judeus e italianos, antes de sua ocupação pelos negros, esses filhos de imigrantes, nascidos norte-americanos, trilharam o caminho típico reservado à segunda geração. Primeiro freqüentaram a escola pública, aprenderam bem o inglês, destacaram-se como alunos brilhantes e encontraram as condições institucionais e culturais necessárias para se tornarem universitários e realizaram o "destino" esperado pelos pais, que depositaram neles todas as esperanças de um futuro melhor e o sonho norte-americano de ascensão social. Mas isso se deu às custas de uma vivência dilacerada, permeada por toda sorte de sentimentos ambivalentes, vividos no registro individual da culpa, do tumulto interno e da vergonha em relação aos progenitores e familiares em geral. Pobres, imigrantes, religiosos, os pais falavam inglês com sotaque e apenas na esfera pública formal, em casa e na vizinhança usavam o iídiche, freqüentavam a sinagoga, trabalhavam duro, divertiam-se pouco. Restritos, de início, à sociabilidade familiar e da vizinhança, pais e filhos, se já não viviam mais confinados em guetos, sentiam que Manhattan era mais longe que a Europa. A proximidade geográfica era atravessada por uma colossal distância social que, quando suplantada pelos filhos, implicou uma viagem sem volta marcada à sinagoga, na suspensão dos preceitos familiares e religiosos dos pais e na adesão a um outro universo de valores: cosmopolita, no plano da cultu- ra, radical, no âmbito da política, agnóstico, avesso, num primeiro momento, às questões religiosas em sua interface com os problemas étnicos.

Atingindo o início da idade adulta num contexto marcado pela grave crise econômica de 1929, eles viveram esse período como um momento paradoxal de liberdade. Nas palavras de um dos editores da Partisan Review, William Barrett, aquilo que Sartre disse a respeito da situação da intelectualidade francesa durante a ocupação alemã ("nunca fomos tão livres" quanto naquele momento) aplica-se com perfeição para descrever a experiência de uma parcela dos artistas e intelectuais (ou candidatos a) nova-iorquinos no período da Depressão. Sem trabalho fixo e sem as obrigações próprias da carreira e da vida profissional, eles puseram a inteligência e a curiosidade a serviço da ampliação dos interesses culturais.

Se a Depressão implicou a suspensão temporária do sonho acalentado pelos pais de ascensão social dos filhos, ela permitiu também que eles se reencontrassem no terreno mais arriscado da política. Como muitos dos imigrantes operários, os pais traziam da Europa a cultura socialista. E foi nesse contexto preciso e, sob muitos aspectos, singular na história norte-americana - no interior do qual a classe operária, os imigrantes e a "plebe" ganharam visibilidade na cena política e na literatura da época - que os filhos desses imigrantes, já antenados com o cosmopolitismo no plano da cultura, por conta de sua socialização na cultura acadêmica da época, aderiram ao marxismo e se enfronharam nas polêmicas travadas entre comunistas e trotskistas. Nas palavras de outro integrante do círculo da Partisan Review, Irving Howe:

[...] o radicalismo dos anos 30 deu aos intelectuais de Nova York o seu estilo distintivo: o faro pela polêmica, o gosto pela grande generalização, uma impaciência com aquilo que eles enxergavam (muitas vezes paroquialmente) como erudição paroquial, uma perspectiva internacionalista, uma crença tácita na unidade - ainda que ela estivesse fora do nosso alcance - do trabalho intelectual (Howe, 1990, p. 244). ${ }^{14}$

A adesão ao marxismo, o afastamento das proposições políticas e culturais do Partido Comu- 
nista, o acirramento da convicção anti-stalisnista (sinalizada com bastante clareza pelo lançamento em 1937 da Partisan Review), a defesa da perspectiva internacionalista, tudo isso correu junto e em meio às transformações da paisagem social e cultural da cidade de Nova York. No âmbito da produção acadêmica, áreas de saber que até então tinham sido monopólio das elites brancas e protestantes, como a filosofia e a literatura inglesa, começaram a ser "invadidas" pelos estudantes judeus mais talentosos, que, minoritários na Universidade de Colúmbia (a instituição universitária de maior prestígio da cidade na época), encontraram na Universidade de Nova York (UNY) e, especialmente no City College, o espaço intelectual necessário para darem prosseguimento aos estudos superiores e à militância política de esquerda. ${ }^{15}$ Havia um clima de urgência no ar e uma sensação de que, malgrado a crise econômica e o medo orquestrado da "ameaça vermelha" representada pela Revolução Russa e perpetrado pela direita, os Estados Unidos poderiam converter-se numa democracia de tipo socialista. Esse tipo de utopia política, acalentado por parcelas minoritárias da cidade mais avançada dos Estados Unidos, palco das vanguardas culturais e artísticas da época, não tardaria a emitir sinais de falência múltipla.

Primeiro, como resultado da entrada dos Estados Unidos na Segunda Guerra Mundial e de sua progressiva hegemonia no plano político e econômico. Segundo, pelas implicações da Guerra Fria, do marcartismo e do anti-comunismo desenfreado que tomou conta das elites políticas norte-americanas, não só das mais alinhadas à direita como de um parcela dos liberais da época. Terceiro, pelo progressivo conservadorismo de muitos dos intelectuais de Nova York, que, marxistas e radicais nos anos de 1930, anti-stalinistas fervorosos nos anos de 1940, defensores do liberalismo e da democracia, inventaram uma ginástica classificatória das mais extravagantes para, na década de 1950, afirmarem-se como "anti-anti-comunistas", parcialmente afinados com os ideários do socialismo democrático, em luta aberta contra todo tipo de totalitarismo. ${ }^{16}$ Por fim, pelo peso que a questão judaica, ausente na perspectiva internacionalista partilhada por eles no decênio de 1930, passou a ter na agenda intelectual dos debates e escritos produzidos no pós-Guerra. A revelação dos campos de concentração, do Holocausto e das atrocidades cometidas durante a Guerra pelos alemães, a ampliação das bases econômicas e sociais da comunidade judaica em Nova York e da influência de seus membros mais expressivos nos círculos culturais de maior prestígio da cidade, o arrefecimento do radicalismo e da visada internacionalista, tudo isso, somado, contribuiu para que os intelectuais nova-iorquinos fizessem uma releitura de suas experiências passadas, sobretudo daquelas relativas à vida em família, e dessem início à problematização de um tema que até então estivera ausente de suas preocupações cosmopolitas: a identidade judaica.

Outsiders, em sua maioria, nos anos de 1930, sob todos os aspectos (origem social, capital cultural e econômico, procedência étnica, filiações doutrinária), os intelectuais de Nova York, sobretudo aqueles ligados às revistas Partisan Review e Commentary, foram paulatinamente migrando não só de posição política como de status intelectual e social. Por volta do final da Segunda Guerra, no momento em que recebiam sinais inequívocos da influência intelectual que exerciam na cidade, eclodiram as primeiras crises internas do grupo. Na visão de Irwing Howe, que pode ser tomada como expressão condensada da autorepresentação desses intelectuais,

[...] talvez houvesse uma relação entre crise interna e influência externa. Tudo aquilo que os mantinha atuantes - a idéia do socialismo, a defesa do modernismo literário, o ataque à cultura de massa, um jeito especial de criticismo literário foi julgado como irrelevante nos anos do pósguerra. Mas como grupo, no momento exato em que a desintegração interna começara seriamente, os intelectuais de Nova York podiam ser prontamente identificados. Os líderes do grupo eram Rahv, Phillips, Trilling, Rosenberg e Kazin. O principal teórico político era Hook. Os escritores e poetas ligados ao meio de Nova York eram Delmore Schwartz, Saul Bellow, Paul Goodman e Isaac Rosenfeld. E scholar o mais reconhecido, assim como a força moral inspiradora, era Meyer Schapiro (Howe, 1990, pp. 251-252). 
Dessa lista, os grandes ausentes são os nãojudeus, como Dwight Macdonald e William Barrett, por exemplo, e as mulheres, como Mary McCarthy, Elizabeth Hardwick, Diana Trilling e Hannah Arendt, reconhecidamente a intelectual mais influente e vigorosa desse círculo, rapidamente incorporada por ele logo após a sua chegada em Nova York em 1941. Seu livro As origens do totalitarismo, escrito no final dos anos de 1940 e publicado em 1951, foi um acontecimento e teve uma recepção estrondosa entre eles.

Nesse mesmo período, no Brasil, os integrantes do Grupo Clima, afinados com os ideários da esquerda, também partilhavam a crítica ao totalitarismo, contrapunham-se ao Partido Comunista, criticavam o stalinismo e defendiam um socialismo de tipo democrático. Mas, diferentemente dos intelectuais nova-iorquinos, que, após a entrada dos Estados Unidos na Guerra e, sobretudo, no pós-Guerra, foram deixando o pólo mais à esquerda do espectro político, os intelectuais de Clima, que, de início, eram mais interessados na agenda cultural do que no debate político (com exceção de Paulo Emílio), passaram a ter uma atuação mais engajada. Primeiro, por meio dos dois manifestos que publicaram na revista Clima (em 1942 e 1943), onde lançaram, segundo Antonio Candido, as bases para a construção de uma ação socialista, "sem sectarismo mas sem transigência", fundada na "fidelidade à Revolução Russa" e no "marxismo como base", mas aberta "às correntes filosóficas e políticas do século" com o propósito imediato de "lutar contra o Estado Novo e o fascismo" (Candido, 1986, p. 61). Em seguida, pelo fato de se manterem como defensores intransigentes da liberdade de expressão e dos valores democráticos, nos dois contextos de maior repressão política no país, o Estado Novo e a Ditadura Militar.

Para além das diferenças políticas e das origens sociais diversas desses dois círculos de intelectuais, eles são um dos produtos mais bem acabados do sistema cultural moderno implantado nas cidades de São Paulo e Nova York no decorrer dos anos de 1930 a 1950, num momento em que a vida acadêmica e a crítica de cultura estavam intimamente entrelaçadas na esfera pública da cidade, nas suas realizações mais expressivas, nos seus projetos mais arrojados.

Ao contrário da maioria dos campi universitários norte-americanos que, em certo sentido, eram e continuam sendo isolados e auto-suficientes em relação ao meio urbano no qual se situam, as instituições de ensino superior em Nova York jamais perderam a conexão com a vida mais ampla da cidade. De fato, elas são impensáveis sem o dinamismo cultural da cidade, o jornalismo, as editoras, os artistas, os museus, as galerias, os intelectuais, os diversos grupos étnicos que, composto por levas de imigrantes, deram uma feição particular à cidade.

Tanto lá como aqui, assiste-se no domínio da produção cultural e intelectual a uma ampliação do recrutamento social de seus praticantes. Exemplar nessa direção são os intelectuais novaiorquinos e, no caso brasileiro, os atores e as atrizes de origem humilde ou imigrante que se incorporaram ao Teatro Brasileiro de Comédia (como Cacilda Becker e Nydia Licia, entre outros) e vários estudantes da Faculdade de Filosofia da Universidade de São Paulo que, uma vez formados, se destacariam nas suas respectivas áreas de especialização. O exemplo mais notório nessa direção é o de Florestan Fernandes. Sua origem social, somada às dificuldades de toda ordem que enfrentara na infância e na adolescência, dificilmente lhe franquearia o ingresso nas faculdades onde se formavam as nossas elites dirigentes, como as de Direito, Politécnica ou Medicina. Do encontro entre jovens talentosos, instituições e projetos arrojados e cidades em intensa transformação com perfil de metrópoles, afastadas dos centros formais de poder político, deu-se a criação das condições sociais e simbólicas para a produção dos círculos de intelectuais rastreados nesse artigo.

\section{Os intelectuais de Nova York vistos pelo prisma da configuração "estabelecidos-outsiders"}

A reorientação política dos intelectuais de Nova York, decorrente em parte da alteração da posição social de seus integrantes e da conquista 
da autoridade cultural e simbólica, parece ser inseparável da consolidação, no pós-Guerra, da hegemonia econômica, militar e política dos Estados Unidos no cenário internacional e da polarização produzida no plano interno pela Guerra Fria. A crítica ao totalitarismo e ao stalinismo ganhou, nesse contexto, alianças inesperadas e conteúdos diversos daqueles exibidos pelo clima de radicalismo dos anos de 1930.17

Essa formulação tem algo de reducionismo político e de "verdade sociológica". Para aplainar os deslizes reducionistas e dar consistência aos eventuais acertos sociológicos, vou utilizar o modelo "estabelecidos-outsiders" de Elias como o propósito de refletir melhor sobre a posição da intelectualidade nova-iorquina. Para resumir um percurso teórico e analítico dos mais vigorosos no campo das ciências sociais, como é o de Norbert Elias, vou apenas sublinhar que as configurações sociais estudadas por ele sob o prisma do modelo mencionado acima permitem apreender, de uma maneira renovada, um conjunto de fenômenos empíricos que, à primeira vista, parecem avessos a uma generalização conceitual mais abrangente. Dentre eles, as relações entre negros e brancos, entre judeus e não judeus, entre burgueses e aristocratas, entre grupos operários idênticos sob qualquer critério morfológico (nível de renda, escolaridade, domicílio, ocupação profissional etc.) e distintos em termos simbólicos. ${ }^{18} \mathrm{Em}$ todas essas relações, sobretudo naquelas que apressada e equivocadamente vêm sendo rotuladas como "étnicas", o que se verifica, segundo a análise de Elias, é a existência de níveis variados de interdependência entre os grupos, expressos por uma distribuição desigual de poder e por processos complexos de atribuição de sentido que enredam todos num jogo dilacerado pela afirmação da superioridade de uns e da inferioridade de outros. Aplicada ao caso das relações entre os alemães e os judeus alemães no final do século XIX, Elias mostra que o ressentimento dos primeiros, os "estabelecidos", em relação aos segundos, era decorrente, em larga medida, do fato destes, os "outsiders", terem começado a ocupar posições de poder e de prestígio tidas até então como monopólio dos "estabelecidos".
Afirmando-se na economia e na cultura, os judeus alemães, vistos como um grupo socialmente inferior, ameaçavam a auto-representação de parcelas expressivas dos alemães. Expresso sob a forma do ressentimento, esse sentimento encontra a sua contrapartida na posição, também em certo sentido "em falso", da sociedade alemã no século XIX. Como mostra Elias,

\begin{abstract}
Faz pouco tempo - somente depois de 1870 que a sociedade alemã dominante passou, ela mesma, de um status relativamente baixo e freqüentemente humilhante em relação aos Estados nacionais europeus considerados estabelecidos, a uma posição de poder relativamente elevada. Em razão desse fato, a consciência que ela tinha de seu status e de sua identidade era particularmente incerta e frágil, comparada àquela de outras nações mais antigas e unificadas há muito tempo. A minoria judia, que constituía uma grupo marginal no país, irritava então especialmente os grupos estabelecidos cristãos e provocava uma animosidade particular porque os próprios grupos estabelecidos, em razão de seu destino, mostravam-se inquietos quanto ao seu status e à sua identidade. [...] Para formular as coisas com mais precisão, poder-se-ia dizer: quanto menos se era seguro de seus status, mais se era anti-semita (1991, pp. 153-154).
\end{abstract}

Essa reflexão de Elias é particularmente sugestiva para lançarmos uma hipótese final sobre a situação dos intelectuais de Nova York ao longo dos decênios de 1930 a 1950 e para entendermos o progressivo conservadorismo político de seus integrantes. Eles, que num primeiro momento, ocupavam uma posição de "outsiders" em relação às elites dirigentes, brancas e protestantes, foram migrando de lugar e tornaram-se os "estabelecidos" no plano cultural e da autoridade intelectual nos anos de 1950.

Um dos sinais inequívocos dessa nova condição é dado pela profusão de memórias e de escritos desses intelectuais a respeito deles mesmos. Tudo se passa como se ao lado da marca que deixaram nos seus respectivos campos de atuação, eles não medissem tempo e energia para recontarem a história do grupo, de forma a aparar as frinchas da imagem que construíram sobre si mesmos. 
Essa busca pelo monopólio da representação legítima e autorizada, recorrente em todos os círculos de intelectuais e artistas com algum destaque na história cultural, ganha contornos específicos no caso dos intelectuais de Nova York. Se tomarmos as diversas reflexões que fizeram sobre eles mesmos como expressões condensadas da auto-representação que gostariam de ver preservadas, talvez possamos descobrir novas pistas de análise.

Vejamos, nesse sentido, como um dos mais argutos integrantes do grupo, o crítico literário e professor universitário Irving Howe, reflete sobre a mudança de status, de reconhecimento social e de posição dos seus pares. A seu ver, isso não implicou na produção de qualquer conexão com

[...] uma classe estável de altos funcionários públicos ou com um segmento significativo dos ricos. Eles não tinham conexões em Washington. Eles não moldaram os gostos oficiais ou dominantes. E não podiam exercer o tipo de controle sobre a opinião cultural que o establishment londrino parece ter logrado manter até recentemente. Críticos como Trilling e Kazin eram ouvidos pelo pessoal do setor editorial. Rosenberg e Greenberg pelas pessoas do mundo da arte, mas dificilmente eles poderiam ser considerados algo tão formidável como um establishment (1990, p. 266).

Se o termo de comparação for o grupo Bloomsbury, ${ }^{19}$ como quer Irving Howe, certamente ele tem razão ao insistir no ponto de que os intelectuais nova-iorquinos não conseguiram o mesmo grau de influência e projeção desfrutado pelo círculo inglês. Entre outras razões, porque os últimos eram oriundos de uma fração dominante da burguesia inglesa. Mas o fato de que as origens sociais assim como a projeção e a influência desses círculos fossem diversas não deve nos impedir de circunscrever algumas das recorrências estruturais observadas na posição dos mesmos. Guardadas as devidas proporções, o círculo de intelectuais de Nova York tornou-se com o tempo tão ou mais estabelecido que o grupo de Bloomsbury. Não porque seus membros tenham enriquecido, estabelecido conexões formais com Washington ou com as elites dirigentes, tampouco porque se concentraram apenas - o que está lon- ge de ser pouco nos anos de 1950 - na crítica da cultura, das artes e da literatura. E sim porque eles se tornaram uma elite cultural exatamente no período em que a sua comunidade "étnica" de origem adquiria posições cada vez mais sólidas em Nova York, que pouco lembravam a situação de seus "parentes pobres" imigrantes.

Uma menção à situação profissional dos membros mais expressivos da Partisan Review no decênio de 1950 é necessária para dar contornos mais consistentes à afirmação acima. Philip Rahv, agnóstico e marxista, fez-se reconhecido por suas intervenções na intersecção da cultura com a política, pela sua capacidade de "farejar" e descobrir jovens escritores, pelos inúmeros ensaios que publicou e organizou sobre literatura russa e norteamericana, especialmente - Dostoievski, Tolstoi e Henry James eram os escritores de sua predileção. ${ }^{20}$ Autodidata, dominava seis línguas (russo, inglês, alemão, francês, hebraico e iídiche) e era um crítico literário renomado quando foi convidado, em 1958, para ser professor de literatura em Brandeis - famoso college de Boston, conhecido por sua ousadia intelectual e institucional, e por contratar um número expressivo de intelectuais judeus, nascidos nos Estados Unidos ou refugiados da Europa, como Herbert Marcuse, por exemplo.

$\mathrm{Na}$ época em que lecionou em Brandeis, Rahv estava casado com Nathalie Swan, sua segunda mulher oficial e terceira relação conjugal, constituída pouco tempo depois de sua separação de Mary McCarthy que, como vimos, o deixara para casar-se com Edmund Wilson. Tendo estudado em Vassar no mesmo período que Mary, Nathalie provinha de uma família rica e era arquiteta de profissão. Nela, Rahv encontraria "a perpétua Guggenheim", ${ }^{21}$ segundo a formulação precisa e irônica de outro membro do círculo, William Barrett.

Um dos poucos não judeus do grupo, mas profundamente identificado com eles, a ponto de se dizer um "assimilado", ${ }^{22}$ Barrett graduou-se em filosofa no City College (integrado por uma maioria de estudantes judeus), antes de ir para a Europa no início dos anos de 1940, onde entraria em contato com o existencialismo francês do qual se tornou especialista. Professor de filosofia da Uni- 
versidade de Nova York (NYU), amigo do poeta e escritor Delmore Schwartz (que também foi editor da Partisan) desde os tempos em que ambos freqüentaram alguns cursos de pós-graduação na Universidade de Colúmbia, Barrett foi colega de departamento de Sidney Hook, a figura mais polêmica do círculo. Marxista convicto nos anos da Depressão, anti-stalinista furioso nas décadas seguintes, ensaísta brilhante, graduado em filosofia no City College, Hook foi professor de filosofia da Universidade de Nova York, onde ingressou em 1931 e permaneceu até a sua aposentadoria. Lá teve como aluno William Phillips, quando este estava fazendo o mestrado, depois de se graduar em filosofia no City College e antes de se doutorar em Colúmbia. Inicialmente comprometido com a literatura proletária e com o radicalismo dos anos de 1930, Phillips, sempre em conjunto com Rahv, distanciou-se definitivamente dos comunistas ao lançar, em 1937, a revista que os tornaria conhecidos na cidade. Seus interesses intelectuais concentravam-se na crítica literária e no jornalismo cultural.

Os críticos de arte da Partisan Review, Clement Greenberg e Meyer Schapiro, eram figuras de destaque nesse campo nos anos de 1950. O primeiro teve uma estréia retumbante na cena cultural nova-iorquina, graças ao artigo "Avant-garde and kitsch", publicado em 1939 na Partisan Review. Defensor intransigente do formalismo no plano analítico e do expressionismo abstrato norte-americano, Greenberg foi o primeiro crítico a reconhecer a importância de Jackson Pollock (contribuindo, assim, para projetá-lo como o pintor norte-americano mais importante na época) e a tratar os artistas modernos de Nova York como parte de uma escola coletiva.

Meyer Schapiro, por sua vez, professor de história da arte em Colúmbia, onde ingressou, aos 16 anos, graças a duas bolsas de estudo que recebeu (Pulitzer e Regents, respectivamente), graduou-se em 1924 e doutorou-se em 1928, no mesmo ano em que começou a ensinar história da arte nessa instituição. Em 1952, tornou-se professor titular de Colúmbia, especializado tanto na arte moderna como na medieval. Reconhecido por seus escritos, por sua erudição, por sua verve como professor, suas aulas tinham um público cativo. Nas palavras de um de seus alunos, Marshall Berman, autor de Tudo que é sólido desmancha no ar, suas aulas eram

[...] como sexo, música ou algumas poucas experiências tão estimulantes: ele nos mostrava a riqueza de existir [...] ele projetava uma corrente impressionante de imagens, modernas e medievais [...] ele fazia ousados saltos ao passado, em culturas radicalmente diferentes, em distintas visões do futuro [...] (Berman, 1996).

As observações apaixonadas do ex-aluno são contrabalançadas, num registro mais irônico, pelos comentários de dois dos seus contemporâneos na Partisan. Afiada, Mary McCarthy alardeava que ele era "uma boca à procura de um ouvido" (apud Barrett, 1982, p. 53). Rahv não deixava por menos ao dizer que após uma hora de conversa telefônica com Schapiro "podia-se obter um PhD” (apud Barrett, 1982, p. 69).

Assim como Schapiro, Lionel Trilling também se graduou em Colúmbia, em 1925. O primeiro judeu a integrar um departamento de literatura inglesa nessa universidade, tornou-se membro estável de seu corpo docente em 1939. Fazendo do ensaio seu meio privilegiado de expressão, autor de estudos importantes sobre a relação entre literatura e psicanálise, Trilling - ao contrário de Schapiro, que segundo seu ex-aluno Berman "banhava-nos na arte que nos fazia ver a alegria e a beleza do mundo moderno" - "forçava-nos a ler a literatura moderna de tal maneira que nos fazia imaginar se ainda sobrava algo para viver" (Berman, 1996). Espécie de livre-pensador, ele foi dentre todos os integrantes do círculo dos intelectuais nova-iorquinos, o mais resistente na atribuição da importância da questão judaica na sua trajetória e formação.

No pólo oposto, encontrava-se Alfred Kazin. O primeiro a editar um livro de memórias voltado para a tematização do seu passado de filho de imigrantes pobres judeus, ele foi também o primeiro membro do grupo a enveredar pelo estudo da formação da tradição literária norte-americana. On native grounds, seu primeiro livro escrito nesta direção, graças a uma bolsa de estudos que recebeu 
da Guggenheim Memorial Foudantion, data de 1942 e foi publicado quando ele tinha 27 anos. O menos engajado do grupo, mais interessado na literatura do que na política, Kazin era um crítico literário renomado nos anos de 1950. Dividia essa posição com Lionel Trilling e Irving Howe.

No caso de Howe, a conquista do nome próprio deu-se, de um lado, pela militância política em 1950, após colaborar com a Partisan Review, onde estreara em 1946, criou Dissent, a revista mais à esquerda no período. De outro lado, pela sua intensa e profícua atividade como resenhista da revista Time, onde trabalhou quatro anos em período parcial. Trotskista na juventude, convocado a servir o exército norte-americano durante a Segunda Guerra, Howe foi enviado ao Alaska nesse período. Encarregado de tarefas burocráticas, dedicou os dois anos passados ali a ler compulsivamente sobre os mais variados assuntos. Os livros eram aqueles disponíveis na biblioteca do acampamento do exército. Mas para a sua sorte, esta era intelectualmente bem equipada, de modo que, encorajado a aprender e impossibilitado de perseguir qualquer especialização, leu e aprendeu muito nesse período. Em suas palavras, "por puro desinteresse da mente, nenhuma universidade que eu tenha conhecido mais tarde se equiparava a esses meses no Alaska" (Howe, 1982, p. 95). Vindo de alguém como ele, que ensinou em universidades do porte de Stanford (entre outras), o comentário dá o que pensar. Formado como a maioria dos judeus do círculo pelo City College, onde se graduou em literatura inglesa, em 1940, Howe estreou como professor universitário em 1953, em Brandeis, onde Rahv também ensinaria, como vimos, a partir de 1958.

Dwight Macdonald, o único jornalista profissional do grupo, oriundo, como vimos, de uma família de classe média protestante e próspera, estudou em escolas particulares, formou-se em Yale, uma das universidades de maior prestígio nos Estados Unidos, integrou o corpo de editores da Partisan Review até o ano de 1943, quando saiu da revista, em razão de discordâncias políticas com os demais editores que defendiam a entrada dos Estados Unidos na guerra, para fundar a Politics, que existiu até 1949. Por fim, é preciso mencionar os nomes de Mary McCarthy, Elisabeth Hardwick, Diana Trilling e Hannah Arendt. Cada uma à sua maneira e em seus respectivos campos de atuação - a primeira como escritora, a última como filósofa e as duas outras como críticas literárias e ensaístas - já tinha conquistado, nos anos de 1950, nome próprio, independentemente das parcerias amorosas. Elas circulavam com autoridade na cena intelectual e cultural da cidade e eram reconhecidas como mulheres brilhantes.

No decênio de 1950, eles e elas formavam uma elite cultural que, distinta do grupo Bloomsbury, não era, como queria Irving Howe, menos "estabelecida" que ele. A diferença entre esses círculos, que existe e precisa ser levada a sério, advém do fato de que os primeiros, os nova-iorquinos, viveram de início os dilaceramentos próprios da condição de "outsiders". Estes, como vimos, exprimiam-se por meio de sentimentos tumultuados e ambivalentes, misto de culpa, vergonha e ressentimento pela origem e condição de seus progenitores. Pais e mães enredados na vida dura de operários, alfaiates, costureiros, pintores de parede, tintureiros, vendedores ambulantes, para quem os filhos eram "o único fim de suas existências", nas palavras de Alfred Kazin - cuja infância e adolescência foi dominada pelo pensamento que repartia o mundo entre os "de dentro e os de fora" (Kazin, 1951, p. 55). Na visão de Irving Howe, "o lar significa privação", por isso a dificuldade em trazer algum amigo não judeu para conhecer sua família. "Eu ficaria envergonhado de mostrar meus pais a ele, assim como de mostrá-lo aos meus pais" (Howe, 1982, p. 5).

A situação que eles viveram de início era completamente distinta (e desconhecida) dos integrantes do grupo inglês que, de tão seguros da sua condição social, podiam-se permitir liberdades ousadas na época, como se referirem a si mesmos pelo primeiro nome e não pelo sobrenome, como era usual entre as elites inglesas. Além disso, é preciso enfatizar que os intelectuais judeus novaiorquinos alcançaram a condição de "estabelecidos" no momento em que a cidade, que dava sentido, direção e vazão à produção (e à sociabilidade) do grupo, se tornara a capital cultural contemporânea e o centro de referência de um 
país que há muito perdera o estatuto de ex-colônia para se transformar na nação mais "estabelecida" do mundo. Prisioneiros dessa condição de "estabelecidos" numa nação "estabelecida", esses intelectuais, ao mesmo tempo em que deixaram marcas indeléveis na cultura norte-americana, viveram a ambivalência decorrente da tentativa de se manterem críticos ao totalitarismo e de se afirmarem às vezes como anti-comunistas, outras como anti-anti-comunistas, num país praticante do pluralismo cultural, mas afeito às lógicas duais no domínio da política.

\section{NOTAS}

1 Este artigo, apresentado no Grupo de Pensamento Social da Anpocs, em outubro de 2002, é parte de uma pesquisa mais ampla desenvolvida junto às bibliotecas e aos arquivos da Universidade de Stanford, Estados Unidos, durante o segundo semestre de 2001 e primeiro semestre de 2002, graças a uma bolsa de pós-doutoramento no exterior que recebi do CNPq. Agradeço aos coordenadores do GT acima mencionado, Fernanda Peixoto e Marcos Chor Maio, pelo incentivo para publicá-lo, e a Ricardo Benzaquén de Araújo pelos comentários feitos por ocasião da apresentação. Sou especialmente grata a Guita Debert, Sergio Miceli e Maria Filomena Gregori pela leitura aguda. Por fim, quero agradecer ao comitê acadêmico da Anpocs pelo parecer instigante que recebi. Incorporei, na medida do possível, algumas das sugestões, reformulei afirmações mais peremptórias ou obscuras, deixei outras em aberto ou inconclusas, para trabalhos futuros.

2 As revistas culturais mais importantes de Nova York nos anos de 1940 e 1950 são uma das fontes privilegiadas para a apreensão das sucessivas transformações nas posições políticas desses intelectuais. Nesse sentido, destacam-se: Partisan Review, criada em 1937; Politics (1944-1949), editada por Dwight Macdonald que, em 1943, deixou o corpo editorial da Partisan, junto com Clement Greenberg; Commentary, fundada em 1945, editada por Eliot Cohen (até o seu suicídio em 1959) e depois por Norman Podhoretz, tinha entre os seus colaboradores o núcleo da intelligentsia norte-americana judaica; Dissent, lançada por Irving Howe e Lewis Coser, em 1950. No campo cultural da época, atravessado por uma série de clivagens de ordem política, enquanto a Partisan Review vai paulatinamente ocupando uma posição de centro, Politics e Dissent situam-se no pólo mais à esquerda e Commentary mantém-se mais à direita.

3 Para um entendimento circunstanciado dos intelectuais de Nova York e do contexto cultural e político no qual estavam inseridos, consultar os livros de James Gilbert (Writers and partisans, 1992), Alexander Bloom (Prodigal sons: the New York intellectuals and their world, 1986), Terry Cooney (The rise of the New York Intellectuals, 1986), Alan Wald (The New York Intellectuals: the rise and decline of the anti-stalinist left from the 1930s to the 1980s, 1987), Neil Jumonville (Critical crossing: the New York intellectuals in postwar America, 1991), David Laskin (Partisans: marriage, politics, and betrayal among the New York intellectuals, 2000), Claudia Pierpont (Passionate minds: women rewriting the world, 2001) e os trabalhos do historiador da cultura, Thomas Bender (New York intellect, 1987; Intellect and public life, 1993, e Budapest and New York [organizado em conjunto com Carl E. Schorkse], 1994).

4 O que de fato aconteceu em 1938, quando Trostsky escreveu o artigo "Art and politics" para o número de agosto-setembro da revista.

5 As informações relativas aos episódios mencionados nessa parte do artigo foram retiradas do livro de Mary McCarthy, Intellectual memoirs (1992).

6 Atestadas, por exemplo, pela atitude da escritora Lillian Hellman, que nos anos de 1980 moveu um processo de danos morais contra Mary envolvendo uma soma significativa de dinheiro, o qual só não chegou à sua tramitação final porque Mary foi acometida por um câncer fatal no pulmão. Apoiada o tempo todo por Hannah Arendt, com quem manteve uma relação intensa de amizade e uma profícua correspondência, Mary McCarthy é uma das mulheres mais interessantes e polêmicas do grupo. Suas memórias, fascinantes do ponto de vista literário e informativo, são um manancial para o aprofundamento das convenções de gênero nos círculos intelectuais de maior prestígio da época.

7 Com exceção de Mary McCarthy, Elizabeth Hardwick, Saul Bellow e Delmore Schwartz, não havia outros escritores dentro do círculo dos intelectuais nova-iorquinos, os quais tinham uma cabeça muito mais crítica do que artística (cf. Jumonville, 1991, p. 9). 
8 A literatura sobre o modernismo é extensa e daria, por si só, um artigo. Para efeitos de "comprovação" da interpretação que estou propondo (e que merece uma reflexão mais alentada, a ser feita em outra ocasião), remeto o leitor interessado no aprofundamento da dimensão de gênero no círculo modernista ao recém-lançado livro de Sergio Miceli, Nacional estrangeiro, 2003.

9 A expressão é do artista plástico Flávio de Carvalho e encontra-se reproduzida no "Roteiro de uma vidaobra", incluído no livro de onde retirei os dados sobre Pagu (cf. Augusto de Campos, 1982, p. 320).

10 Idem, p. 147.

11 Entre os livros de memórias publicados por eles até a metade dos anos de 1960, destacam-se: A walker in the city (1951) de Alfred Kazin, Memoirs of a revolutionist (1957) de Dwight Macdonald, Against the America grain (1962) de Dwight Macdonald, Starting out in the thirties (1965) de Alfred Kazin. A partir do início dos anos de 1970, como resultado do envelhecimento de vários deles, do questionamento que sofreram por parte das gerações mais novas, sobretudo daquelas ligadas à nova esquerda, da publicação do livro de memórias da celebrada dramaturga e escritora Lillian Hellman, Scoundrel time (1976), eles voltam à cena editorial e apostam todas as fichas na reconstrução memorialística de suas trajetórias profissionais, experiências pessoais e engajamentos políticos. O livro de Lillian Hellman, premiado e aclamado pela crítica, sucesso de público, é um libelo contra o macartismo dos anos de 1950 e uma crítica dura ao silêncio de muitos dos intelectuais de Nova York em relação ao período de maior arbitrariedade política da história norte-americana. Uma grande parte dos livros que publicaram a seguir traz senão uma refutação contundente à visão de Lillian Hellman, ao menos uma reconstrução do passado que enfatiza o alinhamento de seus autores no campo político do anti-stalinismo, numa tentativa de demarcarem as suas diferenças em relação ao anticomunismo desenfreado dos conservadores de direita e de enfatizarem a importância que tiveram na cena cultural e editorial. Entre os livros nessa linha, destacam-se: We must march my darlings (1977) de Diana Trilling, Essays on literature and politics (1978) de Philip Rahv, New York Jew (1978) de Alfred Kazin, The Truants (1982) de William Barrett, A view of my own (1982) de Elizabeth Hardwick, A margin of hope (1982) de Irving Howe, $A$ partisan view (1983) de William Phillips, Out of step
(1987) de Sidney Hook, Conversations with Lillian Hellman (1986) editado por Jackson Bryer, Essays, selections (1990) de Irving Howe, Intellectual memoirs (1992) de Mary McCarthy, Writing dangerously (1992) de Carol Brightman, Between friends: the correspondence of Hannab Arendt and Mary McCarthy (1995) editado por Carol Brightman.

12 Como a que ocorreu, por exemplo, na relação dos dois principais editores da Partisan Review, Philip Rahv e William Phillips, que romperam de forma intempestiva na década de 1960, depois de anos de convivência estreita.

13 Se essa observação é corrente nos estudos sobre o modernismo brasileiro, ela ganha uma nova dimensão a partir do instigante estudo de Iná Camargo Costa, Panorama vermelho (2001), voltado para a análise da formação do teatro moderno norte-americano e redigido com o propósito de oferecer uma trama mais consistente para a comparação com a formação do teatro moderno no Brasil.

14 Esta e as demais citações dos intelectuais nova-iorquinos que serão reproduzidas no restante do artigo foram traduzidas pela autora.

15 Segundo Alexander Bloom, a partir dos anos de 1920 observa-se um clima de anti-semitismo nos Estados Unidos, expresso, por exemplo, por meio uma série de restrições que os estudantes judeus começaram a enfrentar nas universidades norteamericanas. Mas, mesmo assim, dois dos maiores colaboradores de Partisan, Lionel Trilling e Meyer Schapiro, ainda puderam, nessa época, se graduar na Universidade de Colúmbia. O que não foi possível aos membros mais novos desses intelectuais judeus, nascidos entre 1915 e 1925. Nenhum deles cursou a Colúmbia. A única alternativa de que dispunham, em razão quer da precária situação familiar, quer do acirramento da discriminação étnica observada nas universidades norte-americanas nos anos de 1930, era o City College. Delmore Schwartz, nesse contexto, foi uma exceção. Oriundo de uma família judia de classe média, graduouse em filosofia, em 1935, na New York University e fez a pós-graduação em Harvard (cf. Alexander Bloom, 1986, cap. 2, "A New York education”, e Shatzky e Taub, 1999).

16 Referência às disputas classificatórias e políticas que tiveram lugar entre os intelectuais de Nova York a partir do início dos anos de 1950, quando Philip Rahv, William Phillips (os principais editores da Partisan), entre outros, criaram o termo "anti-anti- 
comunista" para se diferenciarem, de um lado, do anti-comunismo da direita norte-americana e, de outro, dos anti-comunistas liberais como Sidney Hook e Elliot Cohen (editor da Commentary). Marcando, assim, o seu alinhamento junto à parcela dos "nova-iorquinos" mais à esquerda no período, como Clement Greenberg, Meyer Schapiro, Dwight Macdonald, Irving Howe e Lewis Coser (os dois últimos eram editores da Dissent), entre outros.

17 Cabem aqui esclarecer que a caracterização mais geral do realinhamento político desses intelectuais, feita ao longo do artigo em termos de seu progressivo conservadorismo, corresponde, de um lado, à maneira dominante com que eles foram vistos pela esquerda norte-americana nos anos de 1960 e 1970. Conservadores, neste caso, é um qualificativo atribuído a eles pelos integrantes dessa também chamada "nova esquerda" norte-americana. De outro lado, é preciso salientar que o envolvimento de vários desses intelectuais com organizações que receberam na década de 1960 denúncias por suas ligações supostas ou reais com a CIA contribuiu para o acirramento dessa percepção. Basta mencionar, nesse sentido, a participação de Sidney Hook, Elliot Cohen, William Phillips, Diana Trilling, entre outros, no American Comittee for Cultural Freedom (fundado em 1949) e no Congress for Cultural Freedom, entidades voltadas à defesa da democracia, contra o totalitarismo e o comunismo. Em 1967, veio à tona a informação que a segunda recebia suporte e dinheiro da CIA. O autor da denúncia, Jason Epstein, escreveu o artigo "The CIA and the intellectuals", publicado no New York Review of Books, em abril de 1967. O efeito dessa revelação foi quase o de uma "bomba" a estilhaçar a imagem e a credibilidade política desses intelectuais anticomunistas que se consideravam liberais. A denúncia foi contestada por alguns dos intelectuais citados. Sobre esse assunto, ver Diana Trilling, We must march my darlings, 1977, e Wiliam Phillips, A partisan view, 1983.

18 Ver, nesse sentido, o livro de Norbert Elias e John Scotson, Os estabelecidos e os outsiders (2000). É preciso não esquecer que este livro atualiza uma das dimensões analíticas presentes na figuração "estabelecidos-outsiders". A saber, aquela em que as posições sociais de cada um dos grupos, por estarem assentadas em critérios morfológicos idênticos, ganham uma fixidez no plano da repartição de poderes. Enquanto os recursos simbólicos de cada um dos grupos se mantiverem inalterados, a posição de poder de um sobre o outro permanece a mesma. Isso não quer dizer que o modelo não possa ser aplicado a grupos que, "outsiders" de início, possam vir a se tornar "estabelecidos" ou a ameaçarem a posição dos estabelecidos, como bem mostra Elias em outros trabalhos, notadamente em Os alemães e em Mozart: sociologia de um gênio.

19 Para uma análise densa e provocativa desse círculo, conferir o artigo de Raymond Williams, "The Bloomsbury fraction", 1982, pp. 148-169.

20 A esse respeito, consultar o ensaio memorialístico que Mary McCarthy escreveu sobre Rahv, alguns meses depois da morte dele, para o New York Times Book Review, em 17 de fevereiro de 1974.

21 A observação de Barret refere-se à prestigiada e cobiçada bolsa de estudos fornecida para intelectuais de destaque em diversos campos de conhecimento pela John Simon Guggenheim Memoral Foundation. Transcrita em Andrew Dvosin, Literature in a political world, 1997, p. 103.

22 Comentando a sua identificação com os judeus, William Barrett enfatiza que ela se iniciou de maneira reflexiva e deliberada. Em suas palavras, "I was pro-Jewish because the Jews seemed to me the people of the mind". Cf. The truants, 1982, p. 23.

\section{BIBLIOGRAFIA}

ARRUDA, Maria Arminda do Nascimento. (2001), Metrópole e cultura: São Paulo no meio século XX. Bauru, Edusc.

BARRETT, William. (1982), The Truants: adventures among the intellectuals. Garden City, Anchor Press.

BENDER, Thomas \& SCHORSKE, Carl (orgs.). (1994), Budapest and New York: studies in metropolitan transformations, 1870-1930. Nova York, Russell Sage Foundation.

BENDER, Thomas. (1993), Intellect and public life: essays on the social history of academic intellectuals in the United States. Baltimore, Johns Hopkins University Press.

(1987), New York intellect: a bistory of intellectual life in New York city, from 
1750 to the beginnings of our own time. Nova York, Knopf.

BERMAN, Marshall. (1996), "Meyer Shapiro: the presence of the subject". New Politics, 5 (20).

BLOOM, Alexander. (1986), Prodigal sons: the New York intellectuals and their world. Nova York, Oxford University Press.

BOURDIEU, Pierre. (1984), Homo academicus. Paris, Minuit.

BRIGHTMAN, Carol (org.). (1995), Between friends: the correspondence of Hannab Arendt and Mary McCartby, 1949-197. Nova York, Harcourt Brace \& Co.

. (1992), Writing dangerously: Mary McCarthy and her world. Nova York, Clarkson Potter.

BRYER, Jackson (org.). (1986), Conversations with Lillian Hellman. Jackson, University Press of Mississipi.

CAMPOS, Augusto de (org.). (1982), Pagu: vida e obra. São Paulo, Brasiliense.

CANDIDO, Antonio. (1986), "Informe político", in Carlos Calil e Maria Tereza Machado (orgs.), Paulo Emílio: um intelectual na linha de frente, São Paulo, Brasiliense/Embrafilme.

. (1945), "Depoimento", in Mário Neme (org.), Plataforma da nova geração, Porto Alegre, Globo.

CHAMPION, Laurie (org.). (2000), American women writers, 1900-1945: a bio-bibliographical critical sourcebook. Westiport, Greenwood Press.

CLARK, T. J. (1986), The painting of modern life: Paris in the art of Manet and his followers. Princeton, Princeton University Press.

COONEY, Terry. (1986), The rise of the New York Intellectuals: Partisan Review and its circle. Madison, University of Wisconsin Press.
COSTA, Iná Camargo. (2001), Panorama vermetho: ensaios sobre o teatro americano moderno. São Paulo, Nankin Editorial.

DVOSIN, Andrew. (1997), Literature in a political worl: the carreer and writing of PhilipRabv. PhD. Thesis. New York University.

ELIAS, Norbert. (1991), Norbert Elias par luimême. Paris, Fayard.

ELIAS, Norbert \& SCOTSON, John. (2000), Os estabelecidos e os outsiders: sociologia das relaçôes de poder a partir de uma pequena comunidade. Tradução de Vera Ribeiro, apresentação e revisão técnica de Federico Neiburg. Rio de Janeiro, Zahar

GILBERT, James. (1992), Writers and partisans: a bistory of literary radicalism in America. Nova York, Columbia University Press.

GLUCK, Mary. (1985), Georg Lukács and his generation, 1900-1918. Cambridge, Massachusetts, Harvard University Press.

HARDWICK, Elizabeth. (1982), A view of my own: essays on literature and society. Nova York, Ecco Press.

HELLMAN, Lillian. (1976), Scoundrel time. Boston, Little Brown.

HOOK, Sidney. (1987), Out of step: an unquiet life in the $20^{\text {th }}$ century. Nova York, Harper \& Row.

HOWE, Irving. (1990), Selected writing, 1950-90. Nova York, Harcourt Brace Jovanovich. (1982), A margin of hope: an intellectual autobiography. Nova York, Harcourt Brace Jovanovich.

JUMONVILLE, Neil. (1991), Critical crossing: the New York intellectuals in postwar Ameri$c a$. Berkeley, University of California, Press.

KAUL, Arthur (org.). (1997), American literary journalists, 1945-1995. Detroit, Gale Research. 
KAZIN, Alfred. (1978), New York Jew. Nova York, Knopf.

(1970), On native grounds: an interpretation of modern american prose $1 i-$ terature. Nova York, Harcourt Brace Jovanovich (1 ed. 1942).

(1965), Starting out in the thirties. Ithaca, Cornell University Press.

. (1951), A walker in the city. Nova York, Grove Press.

KRUPNICK, Mark. (1986), Lionel Trilling and the fate of cultural criticism. Evanston, Northwestern University Press.

LASKIN, David. (2000), Partisans: marriage, politics, and betrayal among the New York intellectuals. Nova York, Simon \& Schuster.

MACDONALD, Dwight. (1962), Against the America grain. Nova York, Random House.

. (1957), Memoirs of a revolutionist: essays in political criticism. Nova York, Farrar \& Straus.

MCCARTHY, Mary. (1992), Intellectual memoirs: New York, 1936-1938. Nova York, Harcourt Brace Jovanovich.

. (1987), How I grew. Nova York, Harcourt Brace Jovanovich.

. (1987), Memórias de uma menina católica. Tradução de Heloisa Janh. São Paulo, Companhia das Letras (1 ed. 1955).

MELLO E SOUZA, Gilda. (1984), "Depoimento". Lingua e Literatura, 10-13.

MICELI, Sergio. (2003), Nacional estrangeiro: história social e cultural do modernismo artístico em São Paulo. São Paulo, Companhia das Letras.
PHILLIPS, William (org.). (1985), Partisan Review: the $50^{\text {th }}$ anniversary edition. Nova York, Stein and Day. (1983), A partisan view: five decades of the literary life. Nova York, Stein and Day.

PIERPONT, Claudia. (2001), Passionate minds: women rewriting the world. Nova York, Vintage Books.

PONTES, Heloisa. (1998), Destinos Mistos: os criticos do Grupo Clima em São Paulo, 19401968. São Paulo, Companhia das Letras.

RAHV, Philip. (1978), Essays on literature and politics, 1932-1972 (org. Andrew Dvosin). Boston, Houghton Mifflin.

SHATZKY, Joel \& TAUB, Michael (eds.). (1999), Contemporary Jewish American dramatists and poets: a bio-critical sourcebook. Westport, Conn., Greenwood Press.

SCHORSKE, Carl. (1988), Viena fin-de-siècle: politica e cultura. Tradução de Denise Bottmann. São Paulo, Companhia das Letras.

TRILLING, Diana. (1977), We must march my darlings: a critical decade. Nova York, Harcourt Brace.

WALD, Alan. (1987), The New York intellectuals: the rise and decline of the anti-Stalinist left from the 1930s to the 1980s. Chape Hill, University of North Carolina Press.

WILLIAMS, Raymond. (1982), "The Bloomsbury fraction", in _ Problems in Materialism and Culture, Londres, Verso.

WILSON, Edmund. (1986), Rumo à estação Finlândia: escritores e atores na história. Tradução de Paulo Henrique Britto. São Paulo, Companhia das Letras (1 ed. 1940).

. (1975), Os anos 20: extraído dos cadernos e diários (org. Leon Edel). Tradução de Paulo Henrique Britto. São Paulo, Companhia das Letras. 


\section{CIDADES E INTELECTUAIS: OS "NOVA-IORQUINOS" DA PARTISAN REVIEW E OS "PAULISTAS" DE CLIMA, ENTRE 1930 E 1950}

Heloisa Pontes

\section{Palavras-chave}

Partisan Review e revista Clima; Nova York e São Paulo; Sociologia da vida intelectual; Cultura e política; Cidades, intelectuais e sociabilidade.

$\mathrm{O}$ artigo analisa, numa perspectiva comparativa, as similitudes $\mathrm{e}$ as diferenças entre os intelectuais "nova-iorquinos" nucleados pela Partisan Review e os "paulistas" da revista Clima. Herdeiros todos eles do legado modernista, familiarizados com o cosmopolitismo no plano da cultura, atentos à produção intelectual e artística local, ele marcaram a cena cultural paulista e nova-iorquina dos anos de 1940 e 1950. Os últimos renovaram a discussão sobre a relação entre modernismo nas artes e radicalismo na política. Como intelectuais e escritores, diferenciaram-se dos acadêmicos em sentido estrito. Como críticos e resenhistas, fizeram do ensaio o meio por excelência de expressão e encontraram nas revistas literárias e políticas de Nova York o seu fórum institucional. Parecidos e distintos dos "paulistas" de Clima, eles oferecem um bom contraponto para adensarmos a investigação da vida intelectual em São Paulo no período. Sobretudo, se ao lado da recuperação das especificidades das histórias culturais e intelectuais das cidades de Nova York e São Paulo, formos capazes de avançar na investigação de um conjunto de problemas sociológicos pertinentes para o aprofundamento da perspectiva comparativa.

\section{CITIES AND INTELLECTUALS: THE PARTISAN REVIEW "NEW YORKERS" AND THE CLIMA "PAULISTAS," BETWEEN 1930 AND 1950}

\author{
Heloisa Pontes
}

\section{Key words}

Partisan Review and the Clima magazine; New York and Sao Paulo; Sociology of the intellectual life; Cities, intellectuals, and sociability.

The paper analyses, in a comparative perspective, both the similarities and the differences of the "New Yorker" intellectuals, gathered by the Partisan Review, and the "Paulistas," gathered by the Clima magazine. Being heirs to the modernist legacy, familiarized with cultural cosmopolitanism, and aware of the intellectual and artistic local production, they took the stage in the "Paulista" and "New Yorker" cultural scene in the 1940's and 1950's. The latter could also renovate the discussion on the relationship between modernism in the arts and radicalism in politics. As both intellectuals and writers, they were distinct from the academics in the strict sense. As critics and reviewers, they made the essay their expression means by excellence, finding in the New Yorker literary and political magazines their institutional forum. At the same time similar and distinct to the Clima "Paulistas," they provide a reasonable counterpoint to go deeper in the investigation of the intellectual life in Sao Paulo in that period. That will be done if we, above all, are able to advance over the investigative scope of prevailing sociological problems aside the recuperation of the particularities of the cultural and intellectual history of the cities of New York and Sao Paulo, in order to deepen the comparative perspective.
LES VILLES ET LES INTELLECTUELS: LES NEW-YORKAIS DE LA PARTISAN REVIEW ET LES “PAULISTAS" DE CLIMA, ENTRE 1930 ET 1950

Heloisa Pontes

\begin{abstract}
Mots-clés
Partisan Review et revue Clima; New York et São Paulo; Sociologie de la vie intellectuelle; Culture et politique; Villes, intellectuels et sociabilité.
\end{abstract}

L'article analyse, suivant une perspective comparative, les similitudes et les différences entre les intellectuels newyorkais réunis par la Partisan Review et les "paulistas" de la revue Clima. Héritiers du légat moderniste, familiarisés à un cosmopolitisme sur le plan de la culture et attentifs à la production intellectuelle et artistique locale, ils ont marqué la scène culturelle paulista et new-yorkaise des années 1940 et 1950. Ces derniers ont rénové la discussion à propos de la relation entre le modernisme dans les arts et le radicalisme en politique. En tant qu'intellectuels et écrivains, ils se différencient des académiciens dans le sens strict. En tant que critiques et recenseurs, ils ont fait de l'essai le moyen par excellence de l'expression et ont rencontré dans les revues littéraires et politiques de New York leur forum institutionnel. Semblables et différents des "paulistas" de Clima, ils offrent une bonne contre-mesure pour que l'on puisse approfondir la recherche à propos de la vie intellectuelle à São Paulo au cours de cette période. Particulièrement si, parallèlement à la récupération des particularités des histoires culturelles et intellectuelles des villes de New York et de São Paulo, nous étions capables d'avancer dans la recherche d'un ensemble de problèmes sociologiques pertinents à l'approfondissement de la perspective comparative. 